\title{
May brings money for Malaria research
}

Last month saw the opening of the United States National Institute of Allergy and Infectious Disease (NIAID) new Malaria Vaccine Development Unit (MVDU)-a 70,000 square foot facility located in Rockville, Maryland, with the mandate to fill in the gap between basic research and industrial malaria vaccine production. On the same day, Johns Hopkins Bloomberg School of Public Health announced the creation of a new malaria research institute to focus on basic science funded with $\$ 100$ million from an anonymous donor.

Under the direction of Louis Miller, NIAID's MDVU will provide "product process development," the steps required to take a basic vaccine concept to clinical testing, including initial safety and efficacy assessments. According to Miller, process development has been the bottleneck in malaria vaccine $R \& D$ because private companies are hesitant to invest significant resources in a vaccine that is only needed in developing countries and therefore offers little promise of financial return.

MDVU's role will be to carry out the high-risk work and then look for a company that is willing to take on the Phase III clinical testing. "Finding a company," says Miller "will be a difficult challenge."

MDVU, which will house about 25-30 scientists, will collaborate with scientists in African countries to test its vaccines. Miller predicts that the first vaccine will be taken to Mali in 5-10 years. "It is important to have the partnership of African scientists as they will play a bigger and bigger role in years to come," says Miller.

Meanwhile, the money given for malaria research at Hopkins will allow expansion of the university's existing program. The Bloomberg School of Public Health, which will house the new malaria institute, already has a number of people working in the field. "The goal is to rapidly scale up [operations] over the next 3-4 years," says Dean Alfred sommer.

\section{Laura Bonetta, Bethesda}

\section{Cast your vote}

Nature Medicine would like to canvass your opinion regarding the rescinded appointment of British psychiatrist, David Healy, to the position of Clinical Director of the Mood and Anxiety Disorders Program at the Centre for Addiction and Mental Health, Ontario, Canada and as a Full Professor in the Department of Psychiatry at the University of Toronto (page 643).

We will publish the lecture in question on our homepage and ask you to vote on aspects of its content. Stay tuned to http://www.nature.com/nm/ K.B.

\section{Annan gives prize money to AIDS Fund}

United Nations (UN) Secretary General, Kofi Annan announced last month that he will donate his $\$ 100,000$ award money from the Philadelphia Liberty Medal to the newly proposed UN Global AIDS Fund. Given annually since 1988, the award honors humanitarian efforts and achievements in promoting peace.

The announcement was followed by a pledge of $\$ 200$ million to the fund from the Bush administration with a promise of additional contributions over the next few years. Annan estimates that fund money needs to rise to $\$ 7-10$ billion annually to fight infectious diseases worldwide, particularly the HIV/AIDS epidemic. The fund will support disease prevention as well as treatment with reduced-cost drugs, and a task force, most probably run by the World Bank, will implement the measures. The comprehensive plan will be presented at a special UN session on 25-27 June.

John Schuster, New York

\section{Financial houses scared off by vivisectionist threats}

The Association of Medical Research Charities (AMRC) in the UK has announced its withdrawal of all assets from HSBC after the international bank would not take a tough line against violent animal-rights protestors who continue to threaten the Cambridgeshire-based preclinical testing company, Huntingdon Life Sciences (HLS).

The AMRC has 112 member charities whose combined expenditure on research in the UK amounted to $f 540 \mathrm{mil}$ lion (\$768 million) in 1999/2000. AM RC chief executive, Diana Garnham, told Nature Medicine, "This is not just an issue for Huntingdon but for everyone involved in medical research-all scientists and pharmaceutical companies. We are no longer confident with HSBC's support."
HSBC refused to handle shares in HLS this year following threats from vivisectionists, in particular a group called Stop Huntingdon Animal Cruelty (SHAC). Garnham wrote to HSBC in January questioning the bank's actions and re quested support for her organization if they were similarly threatened. But after an "unsatisfactory response" she believes the bank is too high a risk for the AMRC. Meanwhile, HLS share price has fallen by $76 \%$ in the past year and the company is now valued at $f 7$ million. Protests against HLS-Britain's largest animal-research contractors-have ranged from legal demonstrations to letter bombs by anonymous extremists, targeting employees over the past 16 months.

$\mathrm{HSBC}$ is one of several financial back- ers to have shied away from HLS because of violent threats against employees and shareholders. Others include Merrill Lynch, West LB Panmure, Credit Suisse First Boston, Winterflood Securities, Dresdner Kleinwort Benson, Barclays and internet brokers Charles Schwab Europe. And last month, SHAC members occupied the first floor of the Bank of New York Company's offices in London in protest of the Bank's support for HLS.

The AMRC is currently searching for another bank and is considering advising member charities to also seek new accounts. It is believed the Wellcome Trust, an AMRC member organization, will also withdraw its support from HSBC.

\section{Georgina Kenyon, London}

